\title{
THE ACCURACY OF RISANTO'S FORMULA AND ULTRASOUND MEASUREMENT IN ESTIMATING FETAL WEIGHT
}

\author{
Elsina Pietersz ${ }^{1}$, Irwan Taufiqur Rachman ${ }^{2}$, Risanto Siswosudarmo ${ }^{3}$
}

\begin{abstract}
ABSTRAK
Latar Belakang: Akurasi perkiraan berat janin (EFW) sangat penting dalam menentukan manajemen persalinan. Beberapa metode yang digunakan untuk memperkirakan berat janin seperti palpasi perut, pengukuran tinggi fundus simfisis (SFH), dan pemeriksaan USG. Berdasarkan populasi Indonesia rumus Risanto telah terbukti lebih akurat daripada formula Johnson. Rumusnya adalah sebagai berikut: $Y=125$ $X$ - 880 di mana Y adalah EFW dalam gram, X adalah SFH dalam cm, dan 125 adalah konstanta.

Tujuan: Untuk membandingkan akurasi formula Risanto dan pemeriksaan ultrasound dalam memperkirakan berat janin.
\end{abstract}

Metode: Penelitian potong lintang dilakukan di Rumah Sakit Sardjito, Fakultas Kedokteran Universitas Gadjah Mada, dari Maret 2013 hingga Maret 2014. Sebanyak 400 wanita hamil yang memenuhi kriteria inklusi pada usia kehamilan 37 - 42 minggu direkrut. Perkiraan berat janin menggunakan rumus Risanto (R_EFW) dibandingkan dengan perkiraan berat janin menggunakan pengukuran ultrasound (U_EFW). U_ EFW dilakukan oleh dokter kandungan yang bertugas atau residen senior menggunakan rumus Hadlock. Berat lahir yang sebenarnya (ABW) diukur menggunakan skala bayi yang dikalibrasi yang sama. Akurasi ditentukan dengan membandingkan perbedaan rata-rata antara R_EFW dikurangi $A B W\left(\triangle R \_E F W\right)$ dan U_EFW dikurangi ABW ( $\triangle$ U_EFW). Uji t berpasangan digunakan untuk analisis statistik.

Hasil dan Pembahasan: Rata-rata ABW adalah 3025,3 \pm 414,6 gram dan rerata R_EFW adalah 2972,7 \pm 365,4 gram, sedangkan rata-rata U_EFW adalah 3058,7 $\pm 423,2$ gram. Rerata $\triangle R$ REFW lebih rendah dari mean $\Delta U \_E F W(178,2 \pm 147,6$ gram vs $197,5 \pm 155,4$ gram; $95 \% \mathrm{Cl} 1,24-36,68 ; p=0,04)$.

Kesimpulan: Rumus Risanto lebih akurat daripada pengukuran ultrasound dalam memperkirakan berat janin.

Kata kunci: Perkiraan berat janin, formula Risanto, Ultrasonografi, tinggi fundus

\section{ABSTRACT}

Background: Accurate estimated fetal weight (EFW) is crucial in determining delivery management. Several methods to estimate fetal weight were used such as abdominal palpation, measurement of symphisis fundal height (SFH), and ultrasound examination. Risanto's formula based on Indonesian population had been already proven to be more accurate than Johnson's formula. The formula was as follows: $Y=125 \mathrm{X}$ 880 where $\mathrm{Y}$ was $\mathrm{EFW}$ in grams, $\mathrm{X}$ was $\mathrm{SFH}$ in $\mathrm{cm}$, and 125 was the constanta.

Objective: To compare the accuracy of Risanto's formula and ultrasound examination in estimating fetal weight.

Method: A cross sectional study was carried out in Sardjito hospital, Faculty of Medicine Universitas Gadjah Mada, from March 2013 to March 2014. A total of 400 pregnant women meeting the inclusion criteria at $37-42$ weeks of gestation were recruited. The estimated fetal weight using Risanto's formula (R_EFW) was compared to the estimated fetal weight using ultrasound measurement (U_EFW). The U_EFW was

\footnotetext{
1,2,3 Department of Obstetrics and Gynecology Faculty of Medicine, Public Health and Nursing, Universitas Gadjah Mada/ Sardjito Hospital Yogyakarta
} 
done by obstetricians on duty or senior residents using Hadlock's formula. Actual birth weight (ABW) was measured using the same calibrated baby scale. Accuracy was determined by comparing the mean difference between the $R_{-} E F W$ minus $A B W\left(\triangle R \_E F W\right)$ and the $U \_E F W$ minus $A B W\left(\triangle U \_E F W\right)$. Paired t-test was used for statistical analysis.

Result and Discussion: The mean ABW was $3025.3 \pm 414.6$ gram and the mean R_EFW was $2972.7 \pm 365.4$ grams, while the mean $U_{-} E F W$ was $3058.7 \pm 423.2$ grams. The mean $\triangle R \_E F W$ was lower than the mean $\Delta \mathrm{U} \_$EFW $(178.2 \pm 147.6$ grams vs $197.5 \pm 155.4$ grams; $95 \% \mathrm{Cl} 1.24-36.68 ; p=0.04)$.

Conclusion: Risanto's formula was more accurate than ultrasound measurement in estimating fetal weight.

Keywords: Estimated fetal weight, Risanto's formula, Ultrasonography, Fundal height

\section{INTRODUCTION}

Estimated fetal weight was an important factor in the management of labor and delivery. Extremely small or large birth weight potentially increased perinatal morbidity and mortality. ${ }^{1}$ Accurate birth weight prediction would prevent the complications that might occur. There were two methods used to obtain the estimated fetal weight (EFW), namely by clinical and ultrasound examination. ${ }^{2}$ Clinical examination was done by abdominal palpation and measurement of uterine fundal height (SFH).

There were some clinical methods to estimate fetal weight, all were based on determination of uterine fundal height. They were McDonald's formula, Johnson's formula ${ }^{3}$, and the last was that developed by Siswosudarmo based on Indonesian population. ${ }^{4}$ This formula had been proven to be more effective than Johnson's formula. ${ }^{5}$ Estimated fetal weight based on Risanto's formula (R_EFW) was already available in a form of a table.

Estimated fetal weight by ultrasound examination was calculated by some measurements such as biparietal diameter (BPD), fetal abdominal circumference (AC) and femur length (FL). The formula of Hadlock was used in this study because it was proven to be more accurate than Shepard and Campbell. ${ }^{6}$
The accuracy between clinical and ultrasound examinations for estimating fetal weight varied between investigators. The purpose of the present study was to compare the accuracy of Risanto's formula and ultrasound measurement in estimating birth weight of Indonesian population.

\section{METHODS}

A cross sectional study was carried out in Sardjito hospital, Faculty of Medicine Universitas Gadjah Mada, from March 2013 to March 2014. Inclusion criteria were singleton and fullterm pregnancy, head presentation, with interval of examination to delivery was no more than one week. While the patients would be excluded if there were fetal congenital abnormalities, pregnancy with intra-abdominal tumors, polyhydramnios or oligohydramnios, and subject refused to participate.

The maternal SFH measurement was performed by the following method. The mother was lying in supine position after the bladder was emptied with flexed both of thights and knees. The uterus was held in the midline position by a midwife. Fundal height was palpated using the left four fingers until the radial surface of the left index touched the fundus of uterus. A non elastic flexible sewing tape was put in reverse position 
from the point of fundus following contour of the uterus to symphisis pubis. This measurement was taken twice during no uterine contraction to get the average. The fetus was weighed soon after delivery or maximum during the first 2 hours using the same scale after calibrated to get the ABW.

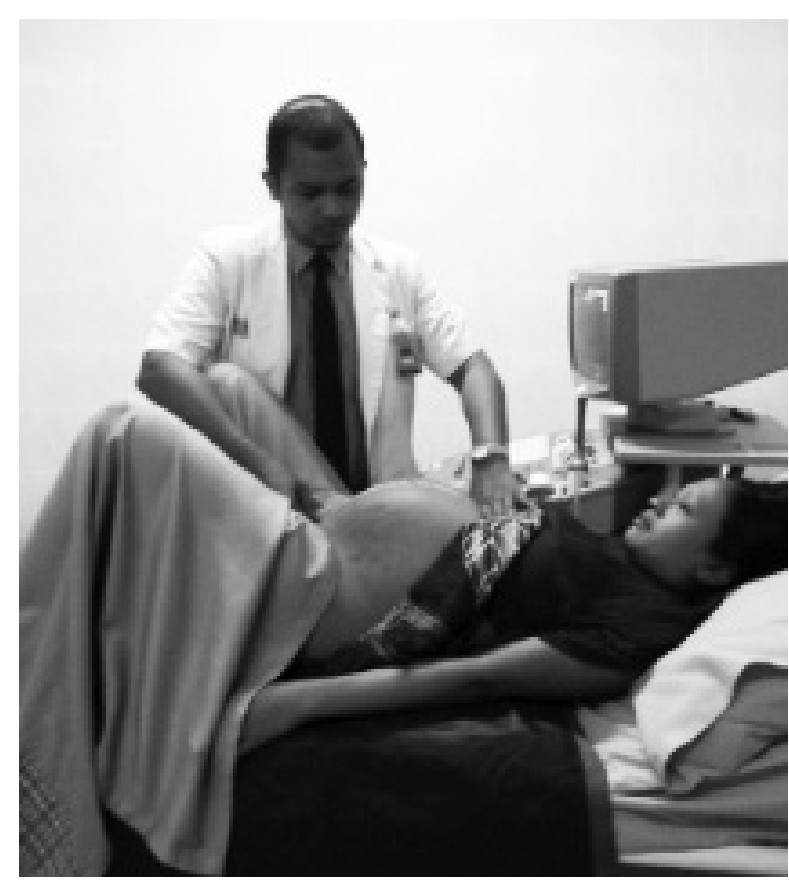

Estimated fetal weight based on Risanto's formula (R_EFW) was calculated by the following formula: $125 \times$ SFH (cm) - 880. Paired t-test was used for statistical analysis. U_EFW obtained from measuring fetal parameters (BPD, AC, FL) using Hadlock formula.USG examinations were performed by obstetricians or senior residents.

Descriptive statistics was used to see the characteristics and central tendencies of the subjects. Paired t-test was used to compare the mean differences of $R_{-} E F W$ to $U_{-} E F W$.
Table 1. Subjects characteristics (N-400)

\begin{tabular}{lrc}
\hline \multicolumn{1}{c}{ Characteristics } & N & Percentage \\
\hline Age (years) & & \\
$\cdot<20$ & 32 & 8,0 \\
$\cdot 20-40$ & 357 & 89,2 \\
$\cdot>40$ & 11 & 2,7 \\
\hline Parity & & \\
$\quad$ Primiparous & 176 & 44,0 \\
- Multiparous & 224 & 56,0 \\
\hline Gestational age (weeks) & & \\
$\cdot$-37-40 & 376 & 94,0 \\
$\cdot>40$ & 24 & 6,0 \\
\hline
\end{tabular}

The descriptive analysis of ABW, R_EFW, U_ EFW showed in Table 2.

Table 2. Central Tendencies of R_EFW, U_EFW, ABW $(\mathrm{N}=400)$

\begin{tabular}{lcccc}
\hline Variables & Min & Max & Mean & SD \\
\hline R_EFW (g) & 2245,0 & 3932,5 & 2972,7 & 365,4 \\
U_EFW (g) & 2102,0 & 4207,0 & 3025,3 & 414,6 \\
ABW (g) & 2045,0 & 4320,0 & 3058,7 & 423,3 \\
\hline
\end{tabular}

Determining the accuracy of Risanto's formula and ultrasound measurement was done by comparing the difference between R_EFW and $A B W$ ( $R \_E F W$ minus $A B W$ or $\triangle R_{-} E F W$ ) with the difference between $U_{-} E F W$ and ABW (U_ EFW minus $A B W$ or $\left.\triangle U_{-} E F W\right)$. Using paired t-test it was shown that the difference was significant (Table 3). 
Table 3. Comparison of $\Delta R_{-} E F W$ and $\Delta U$ _EFW

\begin{tabular}{|c|c|c|c|c|c|c|}
\hline & \multirow{2}{*}{ Mean } & \multirow{2}{*}{ SD } & \multirow{2}{*}{$\Delta$ Mean } & \multicolumn{2}{|c|}{$95 \% \mathrm{Cl}$} & \multirow{2}{*}{$p$ value } \\
\hline & & & & lower & Upper & \\
\hline$\Delta$ R_EFW & 178.5 & 147.6 & 19 & 1.2 & 36.7 & 0,04 \\
\hline
\end{tabular}

As the mean of $\triangle R \_E F W$ (178.5gram) was smaller than the mean of $\Delta U_{-} E F W$ (197.5gram) then it was concluded that Risanto's formula was more accurate than ultrasound measurement.

SFH measurement became unreliable in conditions where pregnancy was complicated by intrabdominal mass such as uterine myoma or ovarian cysts. ${ }^{7}$ Factors influencing the accuracy fetal weight measurements included the interval between examination to delivery, the experience of the examiner, and amniotic fluid index. ${ }^{8,9,10}$

The estimation of fetal weight by ultrasound examination were usually based on the three parameters i.e the measurement of BPD, AC and FL. A review of fetal weight estimation by ultrasound showed that no method was consistently superior to the others. ${ }^{6}$ Studies comparing Hadlock formula and Shepard formula, however, showed that the Hadlock's formula was better than the Shepard's formula, although it was not significant. ${ }^{9}$

This study showed that $\triangle \mathrm{R}$ EFW was smaller than $\triangle U$ UEFW $(178.5 \pm 147.6$ grams vs 197.5 \pm 155.4 grams; $95 \% \mathrm{Cl} 1.2-36.7 ; p=0.04)$. The difference was statistically significant but clinically it was still questionable. However, in some places where specialists or ultrasound machines were not available, Risanto's table could be used for estimating fetal weight.

\section{CONCLUSIONS}

Estimated fetal weight in term pregnancy based on Risanto formula was more accurate than ultrasound examination. The author recommends that Risanto's Table could be used for daily practice and to continue the study for preterm pregnancy.

\section{REFERENCES}

1. Lalys L, Pineau JC, Guihard-Costa a M. 2014. Small and large foetuses: Identification and estimation of foetal weight at delivery from third-trimester ultrasound data. Early Hum Dev. Elsevier Ltd; 2010 Dec [cited 2014 May 29];86(12):753-7. Available from: http://www.ncbi.nlm.nih.gov/ pubmed/20826073

2. Shittu a S, Kuti O, Orji EO. 2014. Comparison of clinical and ultrasonographic estimation of fetal weight. Int J Gynaecol Obstet [Internet]. 2005 Aug [cited 2014 May 29];90(2):140-1. Available from: http://www.ncbi.nlm.nih.gov/pubmed/15963999

3. Numprasert W. 2004. A Study in Johnson's Formula: Fundal Height Measurement for Estimation of Birth Weight. 2004;8(1):15-20.

4. Siswosudarmo R. 2014. Developing New Formula For Estimating Birth Weight at Term Pregnancy. Jurnal Kesehatan Reproduksi:145-149 Vol.1 No.2 Agustus 2014; 2014. p. 145-9.

5. Titisari, Hanifah; Siswosudarmo R. 2013. Risanto's Formula is more Accurate in Determining Estimated Fetal Weight Based on Maternal Height. Indones J Obs Gynecol Vol1, No 3 July 2013.

6. Dudley NJ. 2014. A systematic review of the ultrasound estimation of fetal weight. Ultrasound Obstet Gynecol [Internet]. 2005 Jan [cited 2014 May 27];25(1):80-9. Available from: http://www. ncbi.nlm.nih.gov/pubmed/15505877

7. Morse K, Williams A, Gardosi J. 2009. Fetal growth screening by fundal height measurement. Best Pract Res Clin Obstet Gynaecol [Internet]. 2009 Dec [cited 2014 May 27];23(6):809-18. Available from: http://www.ncbi.nlm.nih.gov/pubmed/19914874 
8. Heer IM, A, Kümper C, Vögtle N, B, Müller-Egloff $S$, et al. 2008. Analysis of Factors Influencing the Ultrasonic Fetal Weight Estimation [Internet]. 2008 [cited2014Jul6].Availablefrom:http://epub.ub.unimuenchen.de/16734/1/10_1159_000116742.pdf
9. Predanic M, Cho A, Ingrid F, Pellettieri J. 2002. Ultrasonographic Estimation of Fetal Weight. 2002;495-500.

10. Perni SC, Predanic M, Cho JE, Kalish RB, Chasen ST. 2004. Association of Amniotic Fluid Index. 2004;i:1449-52. 